\title{
Pelaksanaan Program Pemberian Makanan Sehat Anak Usia Dini : Studi Evaluasi Program CIPP
}

\author{
Dea Ismi Yeni ${ }^{1}$, Heny Wulandari ${ }^{2}$, dan Eti Hadiati ${ }^{3}$ \\ 1,2,3 Program Studi PIAUD, UIN Raden Intan Lampung, Indonesia \\ e-mail : deaismi27@gmail.com¹, heny.piaud@gmail.com², etihadiati117@gmail.com³
}

\begin{abstract}
ABSTRAK. Penelitian ini memiliki tujuan untuk mengevaluasi contexs, input, process dan product program pemberian makanan sehat di TK Negeri Pembina Tanggamus. Penelitian ini adalah jenis penelitian evaluatif dengan pendekatan kualitatif deskriptif, pada penelitian ini menggunakan model evaluasi teori Stufflebeam yaitu CIPP (Context, Input, Process, Product). Data didapat dengan cara wawancara, observasi, dan dokumentasi. Analisis data yang digunakan dalam penelitian ini dengan cara mereduksi data, setelah itu disajikan dalam bentuk deskripsi, dan diverifikasi dengan penarikan kesimpulan. Hasil penelitian ini menunjukkan bahwa: hasil evaluasi dari Context program pemberian makanan sehat menunjukkan bahwa program memiliki tujuan dan perencanaan yang jelas. Hasil evaluasi input program pemberian makanan sehat diketahui bahwa sekolah dan pemerintah memiliki peran yang baik dalam berjalannya program ini. Hasil evaluasi process program pemberian makanan sehat menunjukkan bahwa proses pelaksanaan pemberian makanan berjalan sesuai dengan proser yang telah disediakan oleh puskesmas dan yang menjadi kendala adalah kurangnya kerja sama orang tua dalam memberikan makanan sehat kepada anak pada saat anak dirumah. Hasil evaluasi product/hasil program pemberian makanan sehat menunjukan bahwa pencapaian target berat badan anak sesuai dengan usia nya dan anak tidak ada yang mengalami gizi buruk atau stunting.
\end{abstract}

Kata Kunci : Evaluasi Program, Makanan Sehat, Anak Usia Dini

ABSTRACT. This study aims to: evaluate the context, the, the process and evaluate the product program for providing healthy food in TK Negeri Pembamus Trustees. This research is an evaluative type of research with a descriptive qualitative approach, in this study using the evaluation model of the Stufflebeam theory, namely CIPP (Context, Input, Process, Product). Data obtained by interview, observation, and documentation. Analysis of the data used in this study by reducing the data, after that it is presented in the form of a description, and verified by drawing conclusions. The results of this study indicate that: The results of the evaluation of the Context of a healthy feeding program at TK Negeri Pembina Tanggamus indicate that the program has clear goals and plans. The results of evaluating the input of a healthy feeding program are known that schools and the government have a good role in running this program. The results of the evaluation of the healthy feeding program process show that the process of implementing feeding goes according to the procedures provided by the puskesmas and the problem is the lack of cooperation between parents in providing healthy food to children when the child is at home. The results of product evaluation / healthy food feeding program results in TK Pembina Tanggamus Kindergarten show that the achievement of a child's weight target is in accordance with his age and no child is experiencing severe malnutrition or stunting.

Keyword : Program Evaluation, Healthy Food, Early Childhood 


\section{PENDAHULUAN}

Anak usia dini merupakan generasi masa depan suatu bangsa, pembentukan generasi masa depan bangsa yang kuat, cerdas, kreatif, dan produktif, merupakan tanggungjawab semua pihak. Tumbuh kembang anak secara optimal dalam semua aspek berarti harus mendapatkan perhatian semua pihak. Kebijakan pemerintah ikut mensukseskan terwujudnya suatu generasi bangsa yang kuat, cerdas, kreatif, dan produktif. Salah bentuk program dalam mensukseskan terwujudnya generasi bangsa yang kuat, cerdas, kreatif, dan produktif adalah pemberian makanan sehat. Program pemberian makanan sehat merupakan intervensi untuk pembiasaan makanan sehat dan pembiasaan hidup sehat sebagai penerapan layanan holistic integrative di satuan PAUD/satuan Pendidikan Nonformal (PNF) yang menyelenggarakan program PAUD serta sebagai inisiasi bagi pemerintah daerah untuk menuntaskan stunting di wilayahnya[1]. Pemberian makan sehat yang baik berpengaruh terhadap status gizi (pertumbuhan) balita. Status gizi baik bila tubuh memperoleh asupan gizi yang baik, sehingga memungkinkan pertumbuhan fisik dan Kesehatan secara umum pada keadaan umum sebaik mungkin. Status gizi kurang terjadi bila tubuh mengalami kekurangan atau kelebihan zat gizi. Hasil penelitian Purwani menyimpulkan bahwa ada hubungan antara pola pemberian makan dengan status gizi pada anak usia 1 sampai 5 tahun di Desa Kabunan Kecamatan Taman Kabupaten Pemalang dengan p value sebesar 0,000 yang lebih kecil dari nilai $\alpha(0,05)$. Berdasarkan hasil penelitian memberikan saran untuk ibuibu balita agar memperhatikan pola pemberian makan anaknya agar status gizi balita baik[2].

Menurut Almatsier pola makan adalah suatu usaha dalam pengaturan jumlah dan jenis makanan dengan gambaran informasi meliputi mempertahankan kesehatan, status nutrisi, mencegah atau membantu kesembuhan penyakit serta Konsumsi zat gizi merupakan faktor yang berpengaruh langsung terhadap status gizi[3]. Menurut beberapa ahli keperawatan diantaranya Paplau $\mathrm{H}$ mengatakan bahwa kesehatan adalah proses yang berlangsung mengarah kepda kretifitas, konstruktif, dan produktif. Dengan demikian bahwa kesehatan adalah suatu hal yang tidak dapat dianggap sepele keberadaannya dalam membentuk sumber daya manusia yang unggul. Bidang kesehatan perlu mendapatkan perlakuan dan perhatian khusus guna menunjang kepentingan pembangunan karakter bangsa[4]. Tanda anak sehat menurut Depkes (2009) memiliki kriteria : berat badan naik sesuai garis pertumbuhan mengikuti pita hijau pada Kartu Manuju Sehat (KMS), atau naik ke pita warna di atasnya, anak bertambah tinggi, kemampuan bertambah sesuai usia, jarang sakit, ceria, aktif, dan lincah. Pembentukan kesehatan anak tidak berjalan secara tiba-tiba atau instan, melainkan berproses sejak masa kehamilan sang ibu. Banyak faktor yang mempengaruhi kesehatan anak, antara lain pemberian asi saat bayi, imunisasi, status gizi, dan penyakit infeksi pada anak. Faktorfaktor tersebut berkaitan erat dengan perilaku sehat anak itu sendiri dan perilaku sehat orang-orang terdekat disekitar anak[5]. Menurut Atmojo unsur gizi merupakan salah satu faktor penting dalam pembentukan SDM yang berkualitas yaitu manusia yang sehat, cerdas, dan produktif. Gangguan gizi pada awal kehidupan akan mempengaruhi kualitas kehidupan berikutnya. Gizi kurang pada balita tidak hanya menimbulkan gangguan 
pertumbuhan fisik, tetapi juga mempengaruhi kecerdasan dan produktivitas ketika dewasa[6].

Pola makan pada anak usia dini sangat berperan penting dalam proses pertumbuhan pada anak usia dini, karena dalam makanan banyak mengandung gizi. Membentuk perilaku sehat anak dimulai sejak usia dini. Hal ini dikarenakan usia dini merupakan masa Usia keemasan. Masa Golden Age merupakan masa dimana tahap perkembangan otak pada anak usia dini menempati posisi yang paling vital yakni mencapai $80 \%$ perkembangan otak. Kondisi sehat dapat dicapai dengan mengubah perilaku yang tidak sehat menjadi perilaku sehat dan menciptakan lingkungan yang sehat dan bersih[7]. Membiasakan pola hidup sehat pada anak pada masa pandemi covid-19 dapat dilakukan dengan cara mengingatkan anak untuk memakan-makanan yang bergizi seperti sayur dan buah, berolahraga teratur dan istirahat yang cukup serta berjemur setiap pagi sekitar 10-15 menit. Selain mengingatkan guru juga memberikan kegiatan sederhana kepada anak yang disampaikan melalui rekaman video atau rekaman suara kepada anak. Sedangkan untuk menerapkan pola hidup bersih berdasarkan hasil wawancara dengan guru lembaga PAUD dan orangtua siswa dapat disimpulkan bahwa guru memberikan kegiatan untuk membiasakan pola hidup bersih kepada anak seperti membiasakan anak melakukan cuci tangan dengan sabun, dan menjaga kebersihan diri sendiri. Pembiasaan pola hidup sehat dan bersih dapat terwujud apabila ada kerjasama antara guru dan orangtua[8]. Perilaku hidup bersih dan sehat anak usia dini di lingkungan keluarga sudah berjalan sangat baik di tengah pademi covid 19. Hasil penelitian bahwa penerapan perilaku hidup bersih dan sehat anak usia dini dalam kategori sangat baik, dari data Sebanyak 100\% atau 51 respondenanak cuci tangan dengan sabun sebelum makan. Sebanyak $98 \%$ atau 50 responden anak jika keluar rumah menggunakan masker dan sebanyak $2 \%$ atau 1 responden anak jika keluar rumah tidak menggunakan masker. Sebanyak $100 \%$ atau 51 responden anak jika sudah kembali kerumah langsung mandi dan mengganti baju dan sebanyak 100\% atau 51 responden anak suka berjemur di pagi hari[9].

Menurut departemen kesehatan, pendidikan kesehatan anak usia dini dilakukan oleh orang tua harus didasarkan pada prinsip-prinsip berikut: (1). Berorientasi pada kebutuhan pertumbuhan dan perkembangan anak. (2). Kegiatan pembelajaran dilakukan untuk pemenuhan kebutuhan bermain. (3). Merangsang kreativitas dan inovasi dalam hidup bersih dan sehat. Kreatifitas dan inovasi tercermin melalui kegiatan yang membuat anak tertarik dan menyenangkan. (4). Menyediakan lingkungan dan fasilitas sanitasi kesehatan yang mendukung proses belajar. (5). Mengembangkan kecakapan hidup bersih dan sehat. Kecakapan hidup diarahkan untuk membantu anak menjadi mandiri, disiplin, mampu bersosialisasi dan memiliki keterampilan dasar yang berguna bagi kehidupannya kelak. (6). Menggunakan berbagai sumber dan media belajar yang ada di lingkungan sekitar. (7). Dilaksanakan secara bertahap dan berulang-ulang dengan variasi yang cukup dengan mengacu pada prinsip-prinsip pertumbuhan dan perkembangan anak. (8). Rangsangan pendidikan bersifat menyeluruh mencakup semua aspek kesehatan untuk pertumbuhan dan perkembanagan anak. Tugas pendidik adalah memfasilitasi agar semua aspek perkembangan anak dapat berkembang secara optimal[10]. Perilaku Hidup 
Bersih dan Sehat (PHBS) perlu dikenalkan dan dibiasakan sejak dini sebagai investasi masa depan untuk lingkungan sehat yang lebih baik[11].

Orang tua memiliki peran dalam penerapan perilaku hidup bersih dan sehat anak. Hal ini sesuai dengan hasil penelitian yang menyimpulkan bahwa pola asuh orang tua mempengaruhi perilaku hidup bersih dan sehat anak usia 3 - 4 tahun, kecenderung tidak mandiri pada pola asuh pelindung, permisif, rejektif, dan tidak konsisten serta pemanja PHBS mandiri pada pola asuh penuntut, dominan dan pengkritik[12]. Optimalisasi pertumbuhan dan perkembangan dapat dilakukan dengan me- lalui tiga pilar layanan, yaitu layanan kesehatan, asupan gizi, dan stimulasi psikososial. Pemberian layanan yang te- pat dan berkualitas dapat dilakukan de- ngan baik apabila orang tua, utamanya ibu, pengasuh dan pendidik anak usia dini memiliki pengetahuan dan pemahaman tentang layanan kesehatan, gizi dan stimulasi psikososial sesuai dengan kebutuhan pertumbuhan dan perkem- bangan anak usia dini[13].

Pada saat melakukan pra observasi ke TK Negeri Pembina Tanggamus penulis mewawancarai salah satu guru disana menanyakan tentang keadaan status gizi anak disana, beliau menyampaikan bahwa anak di TK Negeri Pembina bisa dikatakan tidak ada yang mengalami Kekurangan gizi (Stunting) dan perkembangan anak disana cukup baik akan tetapi memang ada 7 anak yang masih terlihat kurus dan berat badan nya tidak sesuai dengan usia nya memang tidak banyak mungkin hanya ada 6 anak. Pendapat tersebut diperkuat dengan melihat data berat badan anak. Dari hasil wawancara dengan Kepala Sekolah Taman Kanak-kanak Negeri Pembina Tanggamus bahwa Taman Kanakkanak ini memang sudah beberapa tahun ini menerapkan Program makanan sehat akan tetapi dalam penyelengaraan pemberian makanan sehat menu makanan nya tidak sesuai dengan ketentuan yang ada di petunjuk teknis pemberian makanan sehat dimana setiap pemberian makanan sehat anak hanya diberikan susu kotak dan makanan ringan sedangkan menurut buku petunjuk makanan yang diberikan adalah jenis makanan lokal yang mengandung protein, karbohidrat, vitamin dan sehat. Selain ini program pemberian makanan sehat ini dalam pelaksanaan nya belum pernah dilakukan evaluasi sehingga membuat penulis tertarik untuk melakukan evaluasi pada program pemerintah yang diberikan kepada sekolah ini.

Tujuan umum program pemberian makanan sehat ini adalah agar Kabupaten Tanggamus tidak termasuk kedalam 100 Kota Stunting di Indonesia, sedangkan tujuan khusus dari program ini meliputi: peserta didik di TK Negeri Pembina tanggamus memiliki kesehatan yang baik sehingga membuat seluruh aspek perkembangan nya berkembang dan gizi nya terpenuhi. Diketahui bahwa tujuan program pemberian makanan sehat di TK Negeri Pembina Tanggamus ini tidak lain untuk memjadikan seluruh peserta didik di sekolah memiliki kesehatan yang baik dan terpenuhi gizi sehingga anak tidak akan mengalami gizi buruk. Selain itu dengan adanya program ini bisa menjadikan orang tua peserta didik menjadi sadar akan pentingnya memenuhi gizi anak. Yang digunakan dalam pemberian makanan sehatpun harus merupakan makanan lokal yang ada didaerah Tanggamus dan memenuhi unsur gizi yang dibutuhkan oleh tubuh anak. Tujuan dari program pemberian makanan sehat ini juga merupakan salah satu upaya yang dilakukan oleh pemerintah untuk menerapkan pola makanan sehat 
sesuai dengan anjuran dinas kesehatan yang memenuhi 4 pilar pedoman gizi seimbang dan 10 pesan umum gizi seimbang sehingga dapat memberantas stunting yang ada dinegara Indonesia.

\section{METODE}

Penelitian ini merupakan penelitian kualitatif dengan bentuk evaluatif dan menggunakan model CIPP yang dikembangkan oleh Stufflebeam ditunjukan untuk menjawab rumusan masalah dalam penelitian ini. Metode kualitatif digunakan agar dapat memperoleh pemahaman dan penafsiran yang relatif mendalam tentang makna dari fenomena yang ada di lapangan. Stufflebeam menyatakan model evaluasi CIPP merupakan model evaluasi komprehensif yang memiliki fungsi formatif dan fungsi sumatif. Fungsi formatif evaluasi adalah memberikan informasi guna memperbaiki dan mengembangkan program sedangkan fungsi sumatif evaluasi adalah memberi pertimbangan untuk menentukan keberhasilan atau kelanjutan program[14].

Model CIPP Stufflebeam digunakan dalam penelitian ini untuk mengevaluasi aspek konteks (latar belakang program, tujuan program, tujuan program), aspek input (rencana isi kegiatan, guru, dan siswa), aspek proses (pelaksanaan program, mekanisme program), dan produk (hasil). Penilitian ini dilakukan di Taman Kanak-kanak Negeri Pembina Tanggamus. Dimana di sekolah ini merupakan salah satu sekolah yang sudah terakreditas. Adapun jumlah peserta didik dalam penelitian ini ialah 50 peserta didik, 4 guru dan 1 kepala sekolah. Penelitian ini dilaksanakan pada semester genap Tahun ajaran 2020/2021 dari bulan Januari sampai bulan Maret di Taman Kanak-Kanak Negeri Pembina Tanggamus. Teknis pengumpulan data dilakukan dengan metode observasi, wawancara dan dokumentasi. Teknis analisis data dilakukan dengan metode reduksi data, display data dan menerik kesimpulan/verifikasi

\section{HASIL DAN PEMBAHASAN}

\section{a. Evaluasi Konteks}

Hasil dari penelitan menemukan bahwa tujuan program pemberian makanan sehat di TK Negeri Tanggamus yang belum tercapai yaitu: menumbuhkan rasa kerja sama yang baik antara guru dan orang tua peserta didik utuk membantu jalannya pemberian program, dalam proses pembuatan makanan dan dalam menerapkan makanan yang sehat kepada anak dirumah. Dapat diketahui bahwa pencapaian dari program pemberian makanan sehat ini adalah sepenuhnya semua anak memiliki berat badan yang ideal dan perkembangnya berkembang secara baik.

Program pemberian makanan sehat memiliki tujuan lain selain menjuhkan anak dari gizi buruk atau stunting dan tujuan yang paling mudah dicapai yaitu menjadikan anak menjadi sadar akan kesehatan setidaknya anak selalu mencuci tangan sebelum makan, anak mau memakan sayuran dan menerapkan prilaku hidup bersih dan sehat disekolah dan menerapkannya juga dirumah. Tujuan dari program pemberian makanan sehat ini memberikan semangat bagi para guru dan sekolah untuk mewujudkan anak 
yang sehat dan cerdas sehingga menciptakan generasi yang baik dimasa mendatang. Tujuan ini tidak mudah dicapai begitu saja tanpa adanya peran serta dari guru yang ada disekolah karena guru disana selalu memberikan pembelajaran mengenai kesehatan dan kebersihan dan mengingatkan anak untuk selalu menerapkan nya juga dirumah. Selain itu ada beberapa orang tua yang mendukung program ini dengan cara menerapkan juga pola makan sehat dirumh agar anak mau membiasakan diri mengkonsumsi makanan sehat. Kerja sama antara puskesmas daerah dengan sekolah jga sangat membantu program ini berjalan dengan baik karena pihak puskeslah yang memberikan menu makanan yang harus diberikan kepada anak sehingga sekolah bisa dengan mudah menerapkan nya dan menjalannya. Sebenarnya tidak hanya anak yang mendapatkan dampak yang baik atas program ini akan tetapi para guru juga memperokeh keuntungan yaitu pengetahuan tentang makanan yang sehat untuk anakanak sehingga membuat mereka terus belajar dan mencari ide bagaimana menyampaikan pentingnya mengkonsusi makanan sehat menjadi suatu pembelajaran yang menarik dan anak bisa menerima pembelajaran tersebut, karena anak yang bersekolah TK lebih percaya perkataan guru nya dan meminta orang tua nya untuk melakukan hal yang diberitahukan oleh guru nya disekolah. Hasil penelitian lain menyimpulkan bahwa Terdapat hubungan positif dan signifikan Pengetahuan Ibu dalam Pemberian Makanan Sehat dengan Status Gizi Anak di SD Negeri 1 Beteng, Kabupaten Magelang, Jawa Tengah. Hal ini ditunjukkan dengan nilai koefisien korelasi (rxy1) sebesar 0,774 dan koefisien determinan sebesar ( 2 xy1) sebesar 0,59[15].

Berdasarkan hasil temuan evaluasi context dalam penelitian ini menyajikan tujuan program, tujuan yang belum dapat tercapai dan tujuan yang mudah dicapai. Ketiga hal tersebut merupakan bagian dari rencana dalam menentukan kebutuhan dan merumuskan tujuan program. Evaluasi Contex tmerupakan situasi atau latar belakang yang mempengaruhi perencanaan program pembinaan. Dengan mengetahui kelemahan dan kekuatan ini, evaluator akan dapat memberikan arah perbaikan yang diperlukan. Ditinjau dari tujuan pencapaian program makanan sehat di TK Negeri Pembina Tanggamus sudah terarah dan terencana dengan baik dan jelas sehingga membantu dalan teealisasinya program. Dan kelemahan yang dimiliki masih banyaknya wali murid yang tidak menyadari bahwa pentingnya makanan sehat bagi perkembang anak sehingga menjadi hambatan agar anak memiliki tubuh yang sehat dan tidak kekurangan gizi.kelebihan dari program ini yaitu adanya semangat dan motivasi yang kuat bagi guru dan pihak sekolah yang besar sehingga mendukung kelancaran menjalankan program pemberian makanan sehat disekolah.

\section{b. Evaluasi Input}

Program pemberian makanan sehat dapat diberikan apabila jumlah peserta didik 20 anak dan di sekolah TK Negeri Pembina peserta didiknya berjumlah 50 anak dan memiliki 2 kelas yaitu kelas A dan B dimana masng-masing jumlah peserta didik 25 anak perkelas ,maka program dapat dilaksanakan dan dapat berjalan sesuai dengan buku panduan yang diberikan oleh pemerintah. Program ini berjalan didalam setiap bulan diberikan sebanyak 4 kali. 
Peran sekolah tentu sangat dibutuhkan dalam pelaksanaan program ini terutama kepala sekolah, guru karena program ini tidak akan berjalan tanpa ada campur tangan pihak sekolah tersebut. Dalam pemberian makanan sehat kepla sekolah memiliki peran menyampaikan amanah dari pemerintah berupa dana untuk pelaksanaan program yang dibuat oleh pemerintah. Dalam melaksanakan program pemberian makanan sehat menjadi lebih mudah dengan adanya peran guru yang ada disekolah selain itu sarana dan prasaranapun diutuhkan dalam program ini seperti menyeidiakan bahan makanan yang akan diberikan, menyiapkan tempat membuat makanan, dan semua itu dilakukan atas kerja sama antara kepala sekolah dan guru serta bahan makanan sehat yang diberikan juga tentunya makanan yang berasal dari yang ada dikotaagung. Selain bahan makanan yang disaipkan sekolah juga harus menyiadakan penujang program ini berjalan dengan baik seprti penyediaan alat kebersihan, alat untuk mencuci tangan, Unit kesehatan sekolah (UKS) semua ada karena adanya peran kepala sekolah sebagai penyedia utama dalam pelaksanaan program ini.

Alat kebersihan disediakan agar dapat digunakan untuk membersihkan kelas dan lingkungan sekolah. Disekolah sudah ada petugas kebersihan untuk menjaga dan membersihan sekolah, semua itu perlu ada karena mnjadi salah satu cara agar kebesihan disekolah dan membuat anak nyaman berada disekolah. Alat mencuci tangan, tentunya ini sangat perlu ada disekolah karena sebelum memakan apapun anak harus mencuci tangan dengan air yang mengalir dan menggunakan sabun agar tidak ada kuman dan bakteri yang masuk ikut bersama makanan yang dimakan peserta didik. Unit Kesehatan Sekolah (UKS) memang sudah ada disekolah ini bahkan sekolah ini merupakan salah satu sekolah Taman Kanak-kanak hijau di Tanggamus. Kegunaan UKS ini sangat banyak selain tempat anak yang sakit disekolah UKS bisa digunakan untuk mengenalkan arti hidup sehat kepada anak.

Program makanan sehat ini bukan hanya kepala sekolah yang ikut andil dalam menjalankan program tetapi semua guru memiliki peran yang sangat penting dalam terlaksananya progam. Agar pemberian makanan tetap berjalan guru harus bekerja sama dalam menyiapkan program dari berbelanja dipsar untuk membeli bahan makanan, memasak makanan sehat dirumah salah satu guru sampai membagikan makanan kepada anak. Kepala sekolah memberikan langsung dana untuk pembelanjaan bahan makanan yang akan dibagikan kepada peserta didik. Selain itu kepala sekolah membuat perkumpulan seperti penyuluhan tentang pentingnya pemberian makanan sehat kepada anak. Didalam perkumpulan orang tua dan guru ini terkadang sekolah mengundang dinas kesehatan untuk menyampaikan materi kepada wali murid yang hadir disekolah, sehingga tidak hanya sekolah saja yang berperan dalam pemenuhan gizi anak tetapi orang tua juga sangat berperan penting dalam pemberian makanan kepada anak dirumah. Dengan adanya kegiatan seperti ini diharapkan seluruh peserta didik di TK Negeri Pembina Tanggamus dalam keadaan gizi yang baik dan tidak terkena stunting serta tercapainya tujuan pemerintah dalam memberantas stunting di Indonesia. Selain itu anak-anak disekolah juga dapat mengetahui pentingnya kesehatan bagi mereka dan perlunya mengkonsumsi makanan yang sehat serta menjaga kebersihan diri. 
Pelaksanaan program pemberian makanan sehat ini tidak akan dapat berjalan dengan baik tanpa adanya peran dari para kader kesehatan yang membantu dalam penyesuaiain menu makanan sehat yang harus diberikan kepada para peserta didik disekolah, selain itu dalam waktu 6(enam) bulan 1(satu) kali petugas kesehatan dari dinas kesehatab datang mengunjungi sekolah dan memberikan wejangan kepada guru dan orang tua/wali murid. Petugas kader kesehatan datang kesekolah tidak setiap minggu tetapi setiap 1 (satu) bulan 1 (satu) kali dalam rangka pengawasan dalam pelaksanaan pemberian makanan sehat di sekolah TK Negeri Pembina Tanggamus.

Pemberian makan sehat adalah program pemerintah yang dilaksanakan sebagai media pengurangan angka stunting yang ada di Indonesia. Pemerintah berperan memberikan dana kepada sekolah dan selanjutnya sekolah akan melakukan setiap langkah pelasanaan program. Dinas kesehatan yang berperan adalah puskemas daerah setempat sejauh ini pusmkesmas Pasar Simpang menjalankan perannya dalam program pemberian tambahan ini adalah dengan cara membuatkan dafatar menu makanan sehat yang harus diberikan kepada peserta didik dan menyiapkan Balai Posyandu didaerah Kampung Baru disana memang dibantu oleh ibu Bhayangkari karena TK Negeri Pembina merukan sekolah yang di dirikan oleh Dinas Pendidikan Tanggamus dan kebetulan letak sekolah ini berada dilingkungan Pemda Tanggamus sehingga yang melakukan Posyandu disana adalah ibu bhayangkari mereka menimbang berat badan setiap anak disana dalam setiap bulannya. Adapun sarana disiapkan oleh pemerintah adalah buku panduan pemberian makanan sehat yang dibuat oleh kementrian kesehatan Indonesia. Buku panduan pemberian makanan sehat merupaka buku yang dibuat oleh kementrian kesehatan dimana didalamnya memuat dasar hukum yang mendasari adanya program ini, tujuan program, dan tata cara dilaksanakannya program. Pendanaan pemberian makanan sehat ini dikirim langsung melalui rekening sekolah oleh pemerintah dengan jumlah dalam tiap semesternya. Sekolah yang mendapatkan dana bantuan pemberian makanan sehat ialah sekolah Negeri milik pemerintah apabila sekolah tersebut swasta maka tidak akan mendapatkan dana bantuan dari pemerintah. Semua syarat dan ketentuan telah dijelaskan dalam buku panduan pemberian makanan sehat yang telah dikeluarkan oleh Dinas berdasarkan dasar hukum yang kuat dan jelas. Dana bantuan akan dikirimkan melalui rekening sekolah yang telah terdaftar dan bukan milik kepala sekolah atau guru yang mengajar di TK Negeri Pembina Tanggamus.

Dari hasil penelitian dapat disimpulkan bahwa para kader kesehatan telah melakukan tugas dengan baik dan selalu melakukan pengawasan dalam tiap 1 bulan 1 kali pada saat pelasanaan pemberian makanan sehat disekolah dan langkah sekolah sangat baik dalam menentukan para kader agar memudahkan program dapat berjalan dengan baik sehingga dapat mencapai tujuan yang diharapkan. Dan penulis melihat secara langsung bahwa memang para kader melakukan perannya dan menyambut dengan baik saat penulis melakukan wawancara kepada ketua kader. Hasil penelitian mennyimpulkan bahwa pemberian makanan sehat berdapat positif untuk Anak usia 1-3 tahun sebagian besar mendapatkan pola pemberian makan tepat dan memiliki status gizi normal di wilayah Kalijudan Kota Surabaya. Anak usia 1-3 tahun yang mendapatkan 
pola pemberian makan tepat akan memiliki status gizi normal di wilayah Kalijudan Kota Surabaya[16].

Berdasarkan dari hasil penelitian dalam mengadakan fasilitas penunjang program pemberian makanan sehat sudah baik dilihat dari sikap pemerintah yang direalisasikan oleh dinas kesehatan dan dijalankan oleh pihak puskesmas daerah kotaagung timur lebih tepatnya puskesmas pasar simpang fasilitas yang diberikan oleh pemerintah berupa uang bantuan yang diberikan langsung oleh pemerintah kepada sekolah dan yang dilakukan oleh puskesmas pasar simpang ialahkepala bagian kesehatan dan gizi turun langsung ke sekolah memastikan keadaan anak serta menyediakan menu makanan sehat yang harus diberikan kepada anak dan memaparkan kandungannya agar dapat membantu guru dalam menyampaikan pembelajaran kepada peserta didik pada saat akan memberikan makanan. Selain itu peran dinas kesehatan ialah melakukan pengukuran tinggi badan penimbangan berat badan anak setiap bulan yang dilakukan oleh ibu-ibu bhayangkari. Selaras dengan evaluasi input salah satunya merupakan sarana dan prasarana yang diberikan oleh pemerintah sudah baik sehingga dapat membuat program pemberian makanan sehat ini terus berjalan dari tahun 2013 hingga saat ini. Pelaksanaan pemberian makanan sehat ini dapat berjalan dengan baik karena adanya pendanaan secara langsung yang diberikan secara langsung oleh pemerintah, disimpulkan dari wawancara yang telah dilakukan kepada kepala sekolah bahwa pendanaan didapat secara langsung ditransfer ke rekening milik sekolah, hasil penelitian ini tidak dapat meilihat secara lagsung bukti-bukti transfer yang ada disekolah karena ini bersifat privasi sekolah.

\section{c. Evaluasi Proses}

Didapat dari hasil penelitian yang dilakukan di TK Negeri Pembina Tanggamus, proses pemberian makanan sehat dilaksanakan 4 (empat) kali dalam 1 (satu) bulan dijam sebelum anak makanan. Pelaksanaan proses pemberian makanan sehat dimulai dengan penyedian menu makanan dan komunikasi terlebih dahulu kepada dinas pendidikan jika akan melakukan program disini yang berperan adalah kepala gizi dan kesehatan puskesmas pasar simpang. Proses pelasanaan pemberian makanan sehat tentu saja dilakukan sesuai dengan buku panduan yang telah disediakan oleh pemerintah dan mengunakan menu makanan yang disedikan oleh pihak puskesmas, Program pemberian makanan sehat di TK Negeri Pembina Tanggamus berjalan sesui dengan panduan yang ada diantara kegiatannya yaitu:

Kegitan persiapan yaitu kegiatan awal dimana kepala sekolah memberikan uang kepada guru yang bertugas berbelanja kemudian dimasak bersama-sama oleh guru dengan menjamin kesehatan nya dan tidak menggunakan pengawet serta perasa buatan dan semua bahan yang mebahayakan. Dalam tahap persiapan ini penulis ikut serta melakukan persiapan bersama para guru berbelanja kebutuhan dan bahan makanan yang akan dibuat menjadi makanan sehat, dari hasil pengamatan yang penulis lakukan semua bahan makanan yang dibeli memanglah produk lokal sebagaimana mestinya yang dianjurkan berdasarkan buku panduan dan semua sudah tersedia dipasar induk Kotaagung dan bahan yang dugunakan dijamin tidak ada yang mengandung bahan 
pengawet semua telah dilakukan dengan baik dan benar sesuai dengan prosedur yang telah dijelaskan oleh para kader kesehatan.

Kegiatan pembuatan makanan yaitu guru membuat makanan sesuai dengan prosedur memasak makanan, guru berbagi tugas dalam pembuatan makanan dan memasak dengan aturan masak yang sehat diamana makanan tidak boleh terlalu matang serta mencuci dahulu makanan yang akan dimasak, menakar besar kandungan dari setiap makanan yang akan dimasak dilihat dari daftar yang sudah diberikan oleh pihak puskesmas. Pembuatan makanan sehat dilakukan secara bersama oleh para guru dan dalam rangka penelitian yang dilakukan oleh penulis maka penulis membantu semua prosedur pelaksanaan program pemberian makanan dalam hal pembuatan penulis ikut berperan dan membantu para guru, dan melihat secara langsung bagaimana para guru memasak makanan yang akan diberikan semua dimasak dengan benar dan sesuai dengan menu makanan sehat yang dianjurkan oleh para kader kesehatan dan semua bahan makanan yang akan dimasak dicuci dengan bersih dengan menggunakan air yang mengalir.

Kegiatan penjelasan makanan yaitu sebelum diberikannya makanan sehat kepada peserta didik guru memberikan penjelasan kepada semua peserta didik tentang apa yang akan dimakan, bahan apa saja yang ada disana, kandungannya serta kegunaan nya bagi tubuh kemudian guru memberikan beberapa pertanyaan agar dapat merangsang otak anak untuk berfikir dan menjawab pertanyaan tersebut, sehingga akan tertanam didalam benak mereka bahwa makanan yang mereka makan memiliki manfaat yang baik bagi tubuh dan agar anak mau memakannya. Hasil pengamatan yang penulis peroleh guru memjelaskan dengan sangat baik makanan yang akan diberikan dengan bahasa anak dimana bahasa tersebut mudah untuk difahami oleh anak dilihat dari antusias anak dalam menjawab pertanyaan dari guru sebelum diberikannya makanan. Dan menurut penulis dalam pelaksanaan pemberian makanan sehat ini sudah baik sekali.

Kegiatan pelaksanaan yaitu kegiatan pemberian makanan kepada setiap peserta didik, agar tidak mengalami kekurangan maka gru harus memastikan makanan yang diberikan kepada anak cukup dan makanan diberikan kepada anak dengan cara mengabsen satu persatu dan sebelum pemberian makanan anak diminta untuk mencuci tangan terlebih dahulu. Pelaksanaan pemberian makanan dilakukan langsun g oleh wali kelas masing-masing dalam kesempatan ini penulis ikut membantu dikelas A dan mengamati bagaimana guru membagikan makanan kepada para peserta didik dengan teliti dan dipastikan tidak ada anak yang tidak mendapatkan makananya. Kegiatan evaluasi dilakukan oleh kepala sekolah, guru yang ada disekolah dimana evaluasi dilakukan pada setiap bulannya semua dilihat dari hasil data berat badan anak dilihat IMT setiap anak apakah anak dalam kata ideal gizi baik atau anak mengalami kurang gizi dengan tidak idealnya berat badan anak. Tahapan yang terakhir ialah evaluasi disini evaluasi dilakukan pada saat setelah anak pulang dari sekolah, penulis meilihat dalam evaluasi ini hanya dilakukan secara obrolan santai saja kemudian kepala sekolah memberikan masukan seperti apa dan bagaimana kedepannya pelaksanaan pemberian 
makanan sehat. Dalam tahap ini menurut penulis evaluasi dilakukan masih kurang baik karena tidak sesuai dengan yang seharusnya dilakukan.

Berdasarkan pernyataan diatas proses pelaksanaan pemberian makanan di TK Negeri Pembina Tanggamus sudah baik penulis mengatakan baik karena penulis langsung melakukan proses pemberian makanan sehat bersama para guru, akan tetapi ada yang harus diperbaiki yaitu evaluasi dalam setiap bulan dimana evaluasi harusnya dilakukan secara benar dan dibahas secara seksama apa yang kurang dan mengapa masih ada anak yang mengalami kurang berat badan semua harusnya dilakukan dengan benar tidak cuek saja. Hal ini sesuai dengan temua penelitian yang menyimpulkan bahwa penyelenggaraan program PAUD Holistik Integratif memiliki landasan hukum Perpres No. 60 Tahun 2013 tentang Holistik Integratif. TK Islam Khaira Ummah telah menggunakan Kurikulum 2013, pembelajaran telah sesuai dengan tahap perkembangan anak dan harapan orang tua, telah memiliki SOP, untuk piket guru, menyambut kedatangan dan kepulangan anak didik. memiliki buku riwayat kesehatan anak, kerjasama dengan puskesmas, dan menyediakan makan siang 4 sehat 5 sempurna dan anak dilarang membeli dan membawa jajanan di kawasan sekolah[17].

Suatu kegiatan atau program yang dilakukan terkadang memiliki hambatan dalam proses pelasanaan. Begitu juga dengan program pemberian makanan sehat di TK Negeri Pembina Tanggamus. Dari hasil penelitian yang dilakukan oleh penulis menemukan beberapa hambatan-hambatan dalam proses pelaksanaan program makanan sehat diantaranya: dalam pelaksanaan pemberian makanan terkadang jumlah peserta didik banyak yang tidak hadir atau bersekolah selain itu hambatan yang ditemukan ketika pelasanaan program ialah kurangnya perhatian dari orang tua peserta didik dimana mereka tidak ingin membantu pelaksanaan pemberian makanan sehat.

Pelaksanaan program pemberian makanan sehat memiliki alokasi waktu empat kali dalam satu bulan. Dalam satu tahun pemberian makanan sehat diberikan sebanyak empat puluh delapan kali. Pelaksanaan pemberian makanan sehat diberikan sesuai dengan jadwal yang diberikan oleh puskesmas. Dalam melaksanakan program pemberian makanan sehat diberikan pada setiap kelas yang didalamnya terdiri dari dua guru kelas dan masing-masing peserta didik 25 anak. Pelaksanaan diberikan secara rutin oleh sekolah dan yang menyiapkan makanan yang akan diberikan adalah para guru. Berdasarkan hasil penelitian yang dilakukan melalui observasi dan wawancara selama pelaksanaan program pemberian makanan sehat berjalan terdapat beberapa hambatan yamg ditemukan yaitu kurangnya kerja sama antara guru dan wali murid dalam pelaksanaan pemberian makanan selain itu terkdang jumlah peseta didik yang masuk sekolah tidak sesuai dengan jumlah biasanya nya sehingga membuat pemberian makanan tidak merata bukan karena kurangnya jumlah makanan tetapi banyak anak yang tidak masuk sekolah. Selain itu hambatan yang dijumpai yaitu kurangnya perhatian wali murid dirumah dalam memberikan makanan kepada anak yang mana seharusnya dirumah anak perlu diberikan makanan sehat agar program ini dapat tercapai secara maksimal dan memuaskan. 


\section{d. Evaluasi Produk}

Pencapaian tujuan dalam program makanan sehat di TK Negeri Pembina Tanggamus menghasilkan Indek Massa Tubuh anak berbeda-beda karena usia anak juga bervariasi. Selama anak dalam usia dini anak memiliki target memiliki IMT yang ideal agar tidak termasuk dalam katagori kekurangan gizi dan yang paling parah adalah membuat anak masuk dalam katagori stunting. Para peserta didik harus mengikuti perintah guru yaitu mengkonsumsi makanan yang telah diberikan pada saat waktu pembagian makanan sehat agar dapat mencapai tujuan dari program pemberian makanan sehat yaitu anak memiliki perkembangan yang sesuai dengan usianya dan memiliki kesehatan yang baik dengan melihat kesetaraan dari berat badan anak dengan usianya. Melihat dari tabel berat badan peserta didik di TK Negeri Pembina Tanggamus berjumlah 50 anak dibentuk 2 (dua) kelas yaitu kelas A dan kelas B. Dari jumlah anak tersebut ada 12 anak yang berat badan kurang dari usia nya dan juga ada 2 anak yang berlebih berat badan nya akan tetapi dalam kategori Ideal pada anak laki-laki dan perempuan usia 5 tahun anak yang memiliki berat badan minimal $13 \mathrm{~kg}$ sampai $24 \mathrm{~kg}$ masih dikatakan ideal. Makan dapat disimpulkan bahwa dalam pencapaian kelayakan program pemberian makanan sehat di TK Negeri Pembina Tanggamus sudah baik karena seluruh anak tidak ada yang mengalami gizi buruk atau stunting.

Dari pernyataan diatas menulis menilai bahwa produk yang dihasilkan dari program pemberian makanan sehat sudah baik dan memeiliki dampak yang positif dimana ditinjau dari tujuan program tersebut ialah mengatasi masalah stunting di Indonesia dan dari hasil yang diperoleh bahwa anak ti TK Negeri Pembina Tanggamus memiliki gizi yang baik dan tidak ada yang mengalami masalah gizi buruk, meskipun ada tujuan yang belum dapat terlaksana ialah terjalain nya kerja sama antara wali murid dan guru dalam penyedian makanan sehat disekolah pada saat jadwal diberikan makanan.

Dari program Pemberian makanan sehat hasil yang dapat dirasakan adalah adanya kegiatan pemberian makanan sehat yang diberikan secara rutin kepada anak setiap 1 (satu) kali seminggu, selain itu sekolah merupakan salah satu sekolah hijau atau Unit Kesehatan Sekolah UKS di Kabupaten Tanggamus karena program pemberian makanan sehat ini membantu terlaksananya perlombaan Unit Kesehatan Sekolah (UKS) tingkat Kabupaten di Tanggamus. Kegiatan lomba ini diharapkan dapat memberikan motivasi kepada sekolah dan orang tua serta menjadikan salah satu media sosialisasi penyampaian himbauan kepada selurah perangkat sekolah baik kepala sekolah, guru, wali murid dan peserta didik agar menjaga kesehatan tubuh dan memperhatikan setiap makanan yang akan dimakan sehingga membuat program ini akan terus berjalan. Selain itu melalui kegiatan lomba Unit Kesehatan Sekolah (UKS) memberikan pembelajaran kepada setiap peserta didik di TK Negeri Pembina Tanggamus selain melatih anak agar memperhatikan kesehatan dan membersihkan diri serta menjaga kebersihan sekolah, rumah dan kelas sejak dini apabila mereka menerapkan itu semua maka setelah dewa anak akan terbiasa melakukannya dan menanamkam didiri setiap anak untuk hidup bersih sehat serta menjaga makan dan mengkonsumsi makanan yang bergizi yang terhindar dari segala macam pengawet, pemanis buatan atau bahan lain yang membahayakan. 
Kegiatan lomba Unit Kesehatan Sekolah (UKS) yang diadakan oleh kabupaten Tanggamus dan Dinas Kesehatan yang diikuti oleh seluruh Sekolah yang ada di Tanggamus, TK Negeri Pembina mampu menjadikan salah satu jalan agar program makanan sehat ini dapat selalu berjalan dengan baik. selain itu dapat memberikan motivasi kepada semua pihak yang ikut bekerja sama dalam perlombaan ini dan dapat menumbuhkan kesadaran akan sayang kepada tubuh dengan menerapkan pola hidup sehat dimanapun berada. Oleh karena itu dilihat dari banyaknya manfaat yang dapat diambil dari kegitan lomba seperti ini harapannya adalah segiatan ini akan menjadi sebuah inspirasi bagi sekolah sehingga membuat sekolah terus berusaha menajdi yang terbaik dan program yang dijalankan oleh sekolah akan berjalan sesuai dengan harapan pemerintah serta harapan yang ada pada semua wali murid. Hasil penelitian lain menyimpulkan bahwa Hasil analisis bivariat dari penelitian ini menunjukkan bahwa secara statistic nilai $\mathrm{p}=000<0,05$ berarti ada hubungan antara praktik pemberian makan dengan status gizi anak usia 3-5 tahun. Dari hasil analisis diperoleh pula nilai OR = 8,89 artinya anak yang kurang optimal dalam pemberian makan mempunyai peluang 8 kali untuk mempunyai status gizi kurus di bandingkan orang tua yang optimal dalam pemberian makan[18].

Apa yang sekolah lakukan dalam mengembangkan program pemberian makanan sehat sudah baik salah satunya sekolah tetap menjaga predikat sekolah sehat di Kabupaten Tanggamus dan memili tujuan yang bisa menghadirkan manfaat yaitu mengevaluasi bagaimana hasil dari program pemerintah yang diberikan dalam bentuk program pemberian makanan sehat untuk mewujudkan anak yang sehat terhindar dari kategori anak stunting atau gizi buruk. Evaluasi produk yang telah ditemukan adalah hasil yang diperoleh dari program Pemberrian makanan sehat dimana seluruh peserta didik di TK Negeri Pembina Tanggamus tidak ada yang mengalami stunting atau gizi buruk. Hasil yang dimaksud merupakan persyaratan sebuah program didirikan untuk mencapai suatu tujuan agar dapat melihat hasil tersebut makan harus diadakan evaluasi. Hal ini diperkuat dengan pernyataan berikut ini: Productis Assessing the outcomen of the programme. Menilai hasil dari sebuah program. Maksudnya ialah menilai hasil yang dicapai dalam penyelenggaraan program tersebut.

\section{KESIMPULAN}

Hasil evaluasi dari Context program pemberian makanan sehat menunjukkan bahwa program memiliki tujuan dan perencanaan yang jelas. Evaluasi input program pemberian makanan sehat diketahui bahwa sekolah dan pemerintah memiliki peran yang baik dalam berjalannya program makanan sehat. Evaluasi process program pemberian makanan sehat menunjukkan bahwa proses pelaksanaan pemberian makanan berjalan sesuai dengan proser yang telah disediakan oleh puskesmas dan yang menjadi kendala adalah kurangnya kerja sama orang tua dalam memberikan makanan sehat kepada anak pada saat anak dirumah. Evaluasi product program pemberian 
makanan sehat menunjukan bahwa pencapaian target berat badan anak sesuai dengan usianya dan anak tidak ada yang mengalami gizi buruk atau stunting di Indonesia.

\section{PENGHARGAAN}

Terima kasih penulis ucapkan kepada kepala sekolah dan para guru yang di TK Negeri Pembina Tanggamus yang telah meluangkan waktunya untuk mengisi instrument penelitian ini dan semua pihak yang telah membantu pelaksanaan penelitian dan penulisan artikel ini. Tidak lupa ucapan terima kasih kepada editor dan reviewer Jurnal Murhum yang sudah memberikan kesempatan sehingga jurnal bisa untuk diterbitkan

\section{REFERENSI}

[1] Dirjend PAUD dan Pendidikan Masyarakat, Petunjuk Teknis Bantuan Pemberian Makanan Sehat Tahun 2018. Jakarta, 2018.

[2] E. Purwani and Mariyam, "Pola Pemberian Makan Dengan Status Gizi Anak Usia 1 Sampai 5 Tahun Di Kabunan Taman Pemalang," J. Keperawatan Anak, vol. 1, no. 1, pp. 30-36, 2013.

[3] A. Amirullah, A. Try, A. Putra, A. Daud, and A. Kahar, "Deskripsi Status Gizi Anak Usia 3 Sampai 5 Tahun Pada Masa Covid 19,” vol. 1, no. 2, pp. 16-27, 2020.

[4] S. Udu, L. O. Anhusadar, A. Alias, and L. Ali, "Hedole Dole: Stunting Tradisional Masyarakat Wakatobi," Al-Izzah J. Hasil-Hasil Penelit., vol. 14, no. 2, p. 32, Dec. 2019.

[5] R. Mardhiati, "Pesan Kesehatan : Perilaku Hidup Bersih Dan Sehat (PHBS) Anak Usia Dini Dalam Kurikulum Pendidikan Anak Usia Dini," p. 368, 2013.

[6] L. Handayani, S. A. Mulasari, N. Nurdianis, F. K. Masyarakat, and U. A. Dahlan, "Evaluasi Program Pemberian Makanan Tambahan Anak Balita Evaluation of Supplement Feeding ' S Programme To Children Under Five Years Old," J. Manaj. Pelayanan Kesehat., vol. 11, no. 01, pp. 21-26, 2008.

[7] Zulfa Husni Khumayra; Madya Sulisno, "Perbedaan Pengetahuan Dan Sikap Perilaku Hidup Bersih," J. Nurs. Stud., vol. 1, no. 1, pp. 197-204, 2012.

[8] H. I. Safitri and H. Harun, "Membiasakan Pola Hidup Sehat dan Bersih pada Anak Usia Dini Selama Pandemi Covid-19," J. Obs. J. Pendidik. Anak Usia Dini, vol. 5, no. 1, p. 385, Jun. 2020.

[9] L. Anhusadar and I. Islamiyah, "Penerapan Perilaku Hidup Bersih dan Sehat Anak Usia Dini di Tengah Pandemi Covid 19," J. Obs. J. Pendidik. Anak Usia Dini, vol. 5, no. 1, p. 463, Jul. 2020.

[10] Heny Wulandari, "Pelaksanaan Pendidikan Kesehatan, Perilaku Hidup Bersih dan Sehat pada Anak Usia Dini," Shautut Tarb., vol. 30, no. 1, pp. 69-85, 2014.

[11] S. K. Moerad et al., "Pendampingan Pelaksanaan Program Perilaku Hidup Bersih dan Sehat (PHBS) Anak Usia Dini - Pos PAUD Terpadu Melati Kelurahan Medokan Ayu - Rungkut Surabaya," Sewagati, vol. 3, no. 3, 2019.

[12] R. S. I. Erik Sulistiana, "Studi Tentang Pola Asuh Orang Tua Terhadap Perilaku Hidup Bersih Dan Sehat Anak Usia 3 - 4 Tahun," Embrio, J. Kebidanan, vol. 2, no. 1, pp. 36-39, 2013.

[13] Hadi Siswanto, "Pendidikan Kesehatan Unsur Utama Dalam Pendidikan Anak Usia Dini," vol. 5, no. 2, pp. 305-322, 2012. 
[14] N. Nurdin and L. O. Anhusadar, "Evaluasi Pelaksanaan Standar Proses di Satuan Pendidikan Anak Usia Dini," J. Obs. J. Pendidik. Anak Usia Dini, vol. 4, no. 2, p. 982, Mar. 2020.

[15] Iska Oktaningrum, "Hubungan Pengetahuan dan Sikap Ibu Dalam Pemberian Makanan Sehat Dengan Status Gizi Anak Di SD Negeri 1 Beteng Kabupaten Magelang Jawa Tengah," J. Student PEND. Tek. BOGA, vol. 8, no. 1, pp. 1-9, 2018.

[16] T. Subarkah and P. D. Rachmawati, "Pola Pemberian Makan Terhadap Peningkatan Status Gizi Pada Anak Usai 1 - 3 Tahun (Feeding Pattern Toward the Increasing of Nutritional Status in Children Aged 1 - 3 Years )," J. Keperatan Anak, vol. 1, no. 1, pp. 146-154, 2012.

[17] L. Lina, D. Suryana, and N. Nurhafizah, "Penerapan Model Evaluasi CIPP dalam Mengevaluasi Program Layanan PAUD Holistik Integratif," J. Obs. J. Pendidik. Anak Usia Dini, vol. 3, no. 2, p. 346, 2019.

[18] Z. P. Perdani, R. Hasan, and N. Nurhasanah, "Hubungan Praktik Pemberian Makan Dengan Status Gizi Anak Usia 3-5 Tahun di Pos Gizi Desa Tegal Kunir Lor Mauk," J. JKFT, vol. 1, no. 2, p. 9, Mar. 2017. 